\title{
Efek konsumsi yoghurt probiotik terhadap kadar low density lipoprotein pada penyandang diabetes mellitus tipe 2
}

\author{
Kartika Yuliani $^{1,2}$, Nyoman Kertia ${ }^{3}$, Lily Arsanti Lestari ${ }^{4 *}$
}

\section{ABSTRACT}

Background : As one of important markers of cardiovascular complication in patients with type 2 diabetes mellitus, low density lipoprotein $(L D L)$ shall be maintained to be in normal range. Based on previous research, consumption of probiotic yogurt contains Lactobacillus acidophilus and Bifidobacterium animalis subsp. Lactis is presumed can improve LDL in patients with type 2 diabetes mellitus but the scientific evidence is still few.

Objectives: To investigate the effect of probiotic yogurt on LDL in patients with type 2 diabetes.

Methods: This study was double blinded randomized controlled trial which was conducted on 32 patientss with type 2 diabetes mellitus. Subjects were divided randomly into 2 groups and given 4 weeks intervention. Subjects in control group were given conventional yogurt while subjects in intervention group were given probiotic yogurt contains L. acidophilus LA5 and B. animalis subsp. Lactis Bb12. Food intake data was collected 4 times using 24-hour recall method during intervention period. LDL of subjects was measured before and after intervention.

Results: There was no significant difference between LDL before and after intervention in control group (128 - $148.5 \mathrm{mg} / \mathrm{dL})$ and intervention group $(130-120.5 \mathrm{mg} / \mathrm{dL})$. Meanwhile, LDL after intervention in control group and intervention group were significantly different ( $p<0.05)$. LDL between energy and macronutrients intake categories were not significantly different.

Conclusion: Probiotic yogurt has a better LDL reduction effect in patients with type 2 diabetes mellitus than conventional yogurt, although the reduction is not significant.

Keywords: type 2 diabetes mellitus; probiotic; yogurt; low density lipoprotein; LDL

\section{ABSTRAK}

Latar Belakang : Sebagai salah satu marker komplikasi kardiovaskuler, kadar LDL pada penyandang diabetes mellitus (DM) tipe 2 harus dijaga agar selalu dalam batas normal. Berdasarkan penelitian-penelitian sebelumnya, konsumsi yoghurt probiotik yang mengandung Lactobacillus acidophilus dan Bifidobacterium animalis subsp. Lactis dianggap dapat memberi efek penurunan kadar LDL pada penyandang DM tipe 2 namun bukti ilmiahnya masih jarang.

Tujuan : Mengetahui efek pemberian yoghurt probiotik terhadap kadar LDL pada penyandang DM tipe 2.

Metode : Desain penelitian ini double blinded randomized controlled trial dengan subjek penyandang DM tipe 2 sebanyak 32 orang yang dibagi menjadi 2 kelompok. Kelompok kontrol diberi yoghurt konvensional sedangkan kelompok intervensi diberi yoghurt probiotik yang mengandung L. acidophilus LA5 dan B. animalis subsp. lactis Bb12. Selama 4 minggu perlakuan, asupan makan subyek diukur sebanyak 4 kali menggunakan metode 24-hour recall. Kadar LDL diukur sebelum dan setelah perlakuan diberikan.

Hasil : Tidak ada penurunan kadar LDL yang signifikan sebelum dan sesudah perlakuan baik pada kelompok kontrol (128 $\mathrm{mg} / \mathrm{dL}-148,5 \mathrm{mg} / \mathrm{dL}$ ) maupun kelompok intervensi $(130 \mathrm{mg} / \mathrm{dL}-120,5 \mathrm{mg} / \mathrm{dL})$. Namun, kadar LDL post test antara kelompok control dan kelompok intervensi berbeda signifikan $(P<0,05)$. Kadar LDL pada masing-masing kategori asupan energi dan makronutrien tidak berbeda signifikan.

Simpulan : Yoghurt probiotik memiliki efek penurunan LDL yang lebih baik daripada yoghurt konvensional walaupun penurunannya tidak signifikan.

Kata Kunci : Diabetes mellitus tipe 2; yoghurt; probiotik; low density lipoprotein; LDL.

\section{PENDAHULUAN}

Bagi penyandang diabetes mellitus (DM) tipe 2, terjadinya komplikasi merupakan hal yang harus dicegah. Komplikasi pada penyandang DM tipe 2 dapat meningkatkan risiko morbiditas dan mortalitas. Komplikasi yang menjadi penyebab utama morbiditas dan mortalitas penyandang DM tipe 2 adalah komplikasi

\footnotetext{
${ }^{1}$ Program Pascasarjana Ilmu Kesehatan Masyarakat, Fakultas Kedokteran, Kesehatan Masyarakat, dan Keperawatan, Universitas Gadjah Mada. Jl. Farmako, Sekip Utara, Yogyakarta 55281, Indonesia

${ }^{2}$ Program Studi Gizi, Fakultas Kesehatan, Universitas Nahdlatul Ulama Surabaya. Jl. Raya Jemursari No. 57 Jemur Wonosari, Wonocolo, Kota Surabaya, Jawa Timur 60237, Indonesia

${ }^{3}$ Departemen Ilmu Penyakit Dalam, Bagian Reumatologi, RSUP Sardjito, Fakultas Kedokteran, Kesehatan Masyarakat, dan Keperawatan, Universitas Gadjah Mada. Jl. Farmako, Sekip Utara, Yogyakarta 55281, Indonesia

${ }^{4}$ Program Studi Gizi Kesehatan, Fakultas Kedokteran, Kesehatan Masyarakat, dan Keperawatan, Universitas Gadjah Mada. Jl. Farmako, Sekip Utara, Yogyakarta 55281, Indonesia

*Korespondensi : E-mail: lily_al@ugm.ac.id, Telp/HP. 087738495045
} 
kardiovaskuler ${ }^{1}$. Salah satu penyebab komplikasi kardiovaskuler pada penyandang DM tipe 2 adalah terjadinya kerusakan endotel sebagai akibat hiperglikemia yang terjadi secara terus menerus dan peningkatan Low Density Lipoprotein (LDL) dalam aliran darah ${ }^{2}$. Oleh karena itu, selain menjaga glukosa darah dari hiperglikemia atau hipoglikemia, penyandang DM tipe 2 juga perlu menjaga profil lipid terutama LDL agar tetap berada pada batas normal.

Upaya-upaya yang perlu dilakukan untuk menjaga LDL tetap normal sekaligus mencegah terjadinya komplikasi kardiovaskuler pada penyandang DM tipe 2 diantaranya pengaturan gaya hidup yang terdiri dari pengaturan makan atau diet, peningkatan aktivitas fisik, penurunan berat badan, dan berhenti merokok ${ }^{3,4}$. Pengaturan makan dengan memilih pangan fungsional seperti yoghurt yang mengandung probiotik saat ini menjadi salah satu alternatif pencegahan sekunder komplikasi penyakit DM tipe 2 yang mulai banyak diteliti ${ }^{5,6}$. Bakteri Lactobacillus reuteri NCIMB 30242 merupakan probiotik yang saat ini diketahui memiliki efek paling baik dalam menurunkan biomarker penyakit kardiovaskuler termasuk LDL. Bakteri lain seperti kombinasi Lactobacillus acidophilus dan Bifidobacterium animalis subsp. lactis juga banyak diteliti untuk menurunkan biormarker kardiovaskuler pada penyandang DM tipe 2, namun keefektifannya masih membutuhkan penelitian lebih lanjut ${ }^{7,8,9}$. Oleh sebab itu, peneliti tertarik untuk melakukan penelitian mengenai efek konsumsi yoghurt probiotik yang mengandung Lactobacillus acidophilus dan Bifidobacterium animalis subsp. lactis terhadap kadar LDL pada penyandang diabetes mellitus tipe 2 .

\section{BAHAN DAN METODE}

Penelitian ini berdesain double-blinded randomized control trial dengan besar sampel 32 orang yang terbagi menjadi 2 kelompok yaitu kelompok kontrol (16 orang) dan kelompok intervensi (16 orang). Subyek direkrut dari 3 Puskesmas di Kota Yogyakarta yakni Puskesmas Gondokusuman 1, Puskesmas Tegalrejo, dan Puskesmas Umbulharjo 2 secara purposive random sampling dengan kriteria inklusi: penyandang DM tipe 2 berusia 30-60 tahun, mengonsumsi obat anti hiperglikemia, tidak mendapat injeksi insulin, tidak mengonsumsi obat anti hiperlipidemia dan hiperkolesterolemia, memiliki lemari pendingin, berdomisi di Kota Yogyakarta, dan bersedia mengikuti penelitian. Kriteria eksklusi penelitian ini diantaranya sedang atau pernah mengalami komplikasi seperti serangan jantung, gangguan ginjal, gangguan hepar, gangguan paru-paru, inflamasi, penyakit kronis di saluran gastrointestinal dan atau gangguan tiroid, intoleransi laktosa, mengonsumsi produk probiotik secara rutin selama 2 minggu sebelum penelitian, serta sedang hamil atau menyusui. Kriteria drop out yang diberlakukan pada penelitian ini yakni meninggal dunia, mengalami komplikasi, mengalami diare, mendapatkan injeksi insulin, dan mengonsumsi antibiotik saat penelitian.

Setelah dirandomisasi, baik kelompok kontrol maupun intervensi diberi perlakuan selama 4 minggu, kelompok kontrol diberi yoghurt konvensional sebanyak $100 \mathrm{ml}$ yang mengandung bakteri S. termophilus FNCC0040 dan L. bulgaricus FNCC-0041 dengan jumlah $>10^{6}$ $\mathrm{CFU} / \mathrm{g}$ setiap hari dan kelompok intervensi diberi yoghurt probiotik sebanyak $100 \mathrm{ml}$ yang mengandung bakteri S. Termophilus FNCC-0040, L.bulgaricus FNCC-0041, L. acidophilus LA-5, dan B. animalis subsp. lactis $B B-12$ dengan jumlah $>10^{6} \mathrm{CFU} / \mathrm{g}$ setiap hari. Sebelum dan sesudah masa perlakuan, kadar LDL subyek diukur. Saat masa perlakuan, asupan makan subyek diukur sebanyak 4 kali menggunakan metode multiple 24-Hour Recall (HR). Seluruh pengambilan data dilakukan oleh peneliti dan enumerator yang telah terlatih. Uji beda kadar LDL pre test dan post test dilakukan menggunakan Uji Wilcoxon, sedangkan uji beda kadar LDL post test antara kelompok kontrol dan kelompok intervensi dilakukan menggunakan Uji MannWhitney. Sebelum dianalisis, data asupan makan subyek dikategorikan menjadi 3 yaitu kurang, sesuai, dan lebih dari anjuran diet diabetes Perkeni $(2015)^{10}$. Kadar LDL post test kelompok kontrol dan kelompok intervensi kemudian dianalisis beda menggunakan uji Kruskalwallis berdasarkan kategori asupan makan tersebut. Keseluruhan uji statistik dilakukan menggunakan aplikasi STATA 13. Sebelum dilakukan, penelitian ini telah lulus ethical clearance dari Komisi Etik Fakultas Kedokteran, Kesehatan Masyarakat, dan Keperawatan UGM dengan nomor: KE/FK/0251/EC/2018.

\section{HASIL}

Subyek penelitian ini sejumlah 32 orang yang terdiri dari $31,25 \%$ laki-laki dan $68,75 \%$ perempuan di kedua kelompok perlakuan. Karakteristik subyek lainnya terdapat pada Tabel 1. Berdasarkan tabel tersebut dapat disimpulkan bahwa tidak ada perbedaan signifikan karakteristik subyek pada kelompok kontrol dan kelompok intervensi sebelum perlakuan dilakukan. Oleh karena itu, subyek pada kelompok kontrol dan kelompok intervensi sebelum perlakuan dapat dianggap sebanding. 
Tabel 1. Karakteristik Subyek

\begin{tabular}{|c|c|c|c|c|}
\hline \multirow{2}{*}{ Variabel } & & \multicolumn{3}{|c|}{ Kelompok } \\
\hline & & Kontrol n (\%) & Intervensi n (\%) & $p$ \\
\hline \multirow[t]{2}{*}{ Jenis kelamin } & Laki-laki & $5(31,25 \%)$ & $5(31,25 \%)$ & $0,648^{1}$ \\
\hline & Perempuan & $11(68,75 \%)$ & $11(68,75 \%)$ & \\
\hline \multicolumn{2}{|l|}{ Usia (tahun) ${ }^{3}$} & $53(9)$ & $56(6)$ & $0,29^{2}$ \\
\hline \multicolumn{2}{|c|}{ Lama terdiagnosa DM tipe $2(\text { minggu })^{3}$} & $48(36)$ & $30(60)$ & $0,98^{2}$ \\
\hline
\end{tabular}

Tabel 2. Berat Badan, Indeks Massa Tubuh (IMT), dan Kadar LDL Subyek

\begin{tabular}{|c|c|c|c|c|}
\hline Variab & & Kelompok Kontrol & Kelompok Intervensi & $p^{\mathbf{b}}$ \\
\hline \multirow{3}{*}{$\begin{array}{l}\text { Kadar LDL } \\
(\mathrm{mg} / \mathrm{dl})\end{array}$} & Pre test ${ }^{1}$ & $128(39)$ & $130(61)$ & 0,29 \\
\hline & Post test ${ }^{1}$ & $148,5(38)$ & $120,5(53)$ & $0,003 *$ \\
\hline & $p^{\mathrm{a}}$ & 0,098 & 0,587 & \\
\hline
\end{tabular}

Selama masa perlakuan, compliance rate subyek penelitian termasuk kategori baik yaitu sebesar $93,75 \%$. Kadar LDL subyek sebelum dan setelah perlakuan terangkum pada Tabel 2. Berdasarkan Tabel 2, tidak ada perbedaan signifikan kadar LDL antara sebelum dan sesudah perlakuan baik pada kelompok kontrol maupun kelompok intervensi. Median kadar LDL sebelum dan sesudah perlakuan pada kelompok kontrol sebesar 128 $\mathrm{mg} / \mathrm{dl}$ dan 148,5 mg/dl. Pada kelompok intervensi, median kadar LDL sebelum dan sesudah perlakuan sebesar $130 \mathrm{mg} / \mathrm{dl}$ dan 120,5 mg/dl. Sebelum perlakuan diberikan, kadar LDL pada kedua kelompok tidak berbeda signifikan $(p=0,29)$. Namun, kadar LDL pada kelompok kontrol dan kelompok intervensi berbeda signifikan setelah perlakuan diberikan $(\mathrm{p}=0,003)$.

Untuk mengetahui ada atau tidaknya perbedaan kadar LDL pada subyek yang termasuk kategori asupan energi dan makronutrien kurang, lebih, atau sesuai dengan anjuran, peneliti melakukan analisis statistik dengan hasil yang terangkum pada Tabel 3. Berdasarkan data pada Tabel 3, tidak ada perbedaan kadar LDL post test di antara kelompok pada kategori asupan energi, kategori asupan karbohidrat, kategori asupan lemak, dan kategori asupan protein.

Tabel 3. Kadar LDL Berdasarkan Kategori Asupan Energi dan Makronutrien

\begin{tabular}{|c|c|c|c|c|c|}
\hline \multirow{2}{*}{\multicolumn{2}{|c|}{ Kategori Asupan Energi dan Zat Gizi }} & \multicolumn{2}{|c|}{ Kelompok Kontrol (P1) } & \multicolumn{2}{|c|}{ Kelompok Intervensi (P2) } \\
\hline & & $\mathbf{n}$ & Kadar LDL post test ${ }^{\mathrm{a}}$ & $\mathbf{n}$ & Kadar LDL post test $^{\mathrm{a}}$ \\
\hline \multirow[t]{3}{*}{ Energi $^{2}$} & Kurang $(<80 \%)$ & 9 & $150,44 \pm 27,06$ & 11 & $109 \pm 35,96$ \\
\hline & Sesuai $(80-110 \%)$ & 7 & $139,29 \pm 21,75$ & 4 & $110,75 \pm 30,11$ \\
\hline & Lebih $(>110 \%)$ & 0 & - & 1 & $145 \pm 0$ \\
\hline nilai $p^{1}$ & & & 0,34 & & 0,42 \\
\hline \multirow{3}{*}{ Karbohidrat $^{3}$} & Kurang $(<45 \%)$ & 7 & $148,14 \pm 30,57$ & 4 & $107 \pm 36,47$ \\
\hline & Sesuai $(45-65 \%)$ & 9 & $143,55 \pm 20,91$ & 11 & $110,36 \pm 34,11$ \\
\hline & Lebih $(>65 \%)$ & 0 & - & 1 & $145 \pm 0$ \\
\hline nilai $p^{1}$ & & & 0,79 & & 0,38 \\
\hline \multirow[t]{3}{*}{ Lemak $^{3}$} & Kurang $(<20 \%)$ & 4 & $151,75 \pm 24,29$ & 2 & $104,5 \pm 51,62$ \\
\hline & Sesuai $(20-25 \%)$ & 9 & $150 \pm 24,82$ & 11 & $104,73 \pm 32,73$ \\
\hline & Lebih $(>25 \%)$ & 3 & $124 \pm 19,52$ & 3 & $142 \pm 6,08$ \\
\hline nilai $p^{1}$ & & & 0,19 & & 0,12 \\
\hline \multirow[t]{3}{*}{ Protein $^{3}$} & Kurang $(<10 \%)$ & 5 & $147 \pm 23,57$ & 4 & $82,25 \pm 43,96$ \\
\hline & Sesuai $(10-20 \%)$ & 11 & $144,91 \pm 26,36$ & 11 & $119,36 \pm 24,13$ \\
\hline & Lebih $(>20 \%)$ & 0 & - & 1 & $145 \pm 0$ \\
\hline nilai $p^{1}$ & & & 0,86 & & 0,13 \\
\hline
\end{tabular}

${ }^{\mathrm{a}}$ : Data ditampilkan dalam bentuk rata-rata \pm simpangan baku $;{ }^{1}:$ Nilai $p$ berdasarkan uji kruskal-wallis $;{ }^{2}:$ Persentase dari total kebutuhan energi yang dihitung menggunakan rumus Perkeni $(2015) ;{ }^{3}$ : Persentase dari total pengeluaran energi, kategori asupan mengacu dari panduan diet diabetes Perkeni (2015)

\section{PEMBAHASAN}

Bakteri probiotik telah diketahui memiliki efek terhadap perbaikan profil lipid dan glukosa darah pada hewan coba. ${ }^{11,12}$ Oleh karena itu, penelitian terkait efek probiotik terhadap profil lipid dan glukosa darah kini mulai banyak dilakukan pada manusia. Pada penelitian ini, penulis melakukan uji efek probiotik L. acidophilus $L A-5$, dan B. animalis subsp. lactis BB-12 dalam bentuk yoghurt terhadap kadar LDL penyandang diabetes mellitus tipe 2. Hasil penelitian ini membuktikan bahwa tidak ada penurunan signifikan kadar LDL pada penyandang DM tipe 2 setelah pemberian yoghurt konvensional baik pada kelompok kontrol maupun 
yoghurt probiotik pada kelompok kontrol $(\mathrm{p}>0,05)$. Meskipun demikian, terdapat perbedaan signifikan kadar LDL post test antara subyek pada kelompok kontrol dan kelompok intervensi.

Penelitian sebelumnya yang dilakukan oleh Ivey et al. menunjukkan bahwa tidak ada perbedaan signifikan pemberian yoghurt probiotik dan yoghurt konvensional terhadap kadar LDL pada penyandang DM tipe $2^{13}$. Pada penelitian lain, pemberian yoghurt probiotik terbukti dapat menurunkan kadar LDL secara signifikan namun pemberian yoghurt konvensional tidak memberi efek penurunan yang signifikan terhadap kadar LDL penyandang DM tipe $2^{6}$. Efek probiotik memang sangat beragam karena bersifat strain-dependent. Pada review dari empat uji klinis yang dilakukan oleh Dirienzo, probiotik kombinasi L. acidophilus LA-5, dan $B$. animalis subsp. lactis $B B-12$ terbukti dapat menurunkan kadar LDL yang signifikan ${ }^{7}$.

Faktor yang diduga menjadi penyebab efek yoghurt probiotik yang tidak signifikan pada penelitian ini adalah faktor individu atau subyek penelitian. Karakteristik individu yang berbeda pada setiap penelitian dapat mempengaruhi hasil penelitian. Sebagai contoh, individu yang mengonsumsi makanan dengan kandungan asam lemak tidak jenuh yang tinggi akan mengalami peningkatan jumlah bakteri Streptococcus, Lactobacillus, Bifibacteria, dan Akkermansia muciniphila dalam usus. Hal ini dapat membantu efek dari yoghurt probiotik untuk menurunkan kadar LDL. Sebaliknya, inidividu yang mengonsumsi makanan tinggi asam lemak jenuh akan cenderung mengalami peningkatan jumlah bakteri Bacteriodes, Bilophila, dan Faecalibacterium prausnitzii yang dapat menurunkan sensitivitas insulin dan meningkatkan inflamasi jaringan lemak putih ${ }^{14}$. Oleh sebab itu, asupan makan individu menjadi faktor penting yang perlu dipertimbangkan saat melihat efek konsumsi yoghurt probiotik ataupun produk probiotik lainnya.

Pada penelitian ini terbukti bahwa tidak ada perbedaan signifikan kadar LDL post test antara kategori asupan karbohidrat, protein, dan lemak. Berdasarkan review yang dilakukan oleh Singh et al., konsumsi makanan tinggi protein terutama dari protein hewani terbukti dapat meningkatkan jumlah Bifidobacteria, Bacteriodes, Alistipes, Bilophila, Clostridia, Roseburia, dan Eurobacterium rectale dalam usus. Beberapa jenis bakteri seperti Bifidobacteria, Bacteriodes dan Eurobacterium rectale juga mengalami efek penurunan akibat asupan tinggi protein hewani. Bifidobacteria merupakan bakteri yang memberi efek positif terhadap profil lipid namun Bacteriodes, Alistipes, dan Bilophila justru memiliki efek terhadap peningkatan Trimethylamine $N$-oxide (TMAO) yang dapat memicu terjadinya penyakit kardiovaskuler. Asupan tinggi lemak dapat menyebabkan peningkatan jumlah bakteri Lactobacillus, Streptococcus, Clostridiles dan
Bacteriodes, sedangkan asupan rendah lemak dapat meningkatkan Bifidobacteria. Asupan tinggi karbohidrat dalam bentuk glukosa terbukti dapat meningkatkan jumlah Bifidobacteria dan menurunkan jumlah Bacteriodes dalam usus ${ }^{14}$.

Meskipun beberapa makronutrien seperti protein dan karbohidrat (glukosa) dapat memicu peningkatan jumlah bakteri gram positif yang dapat membantu kerja probiotik, nyatanya kadar LDL subyek tidak berbeda signifikan antara masing-masing kategori asupan pada penelitian ini. Beberapa zat gizi lain seperti asam lemak jenuh, asam lemak tidak jenuh, dan serat yang telah terbukti secara ilmiah memiliki efek terhadap perbaikan profil lipid (termasuk kadar LDL) dapat dipertimbangkan untuk menjadi variabel luar pada penelitian efek yoghurt probiotik atau produk probiotik lainnya terhadap profil lipid penyandang diabetes mellitus tipe $2^{14,15}$. Hal ini perlu dilakukan agar efek probiotik terhadap profil lipid penyandang diabetes mellitus tipe 2 dapat diungkap dengan lebih jelas.

Uji beda yang tidak signifikan antara kadar LDL pre test dan post test pada kelompok intervensi setelah pemberian yoghurt probiotik juga dapat disebabkan oleh durasi pemberian perlakuan yang kurang lama. Berdasarkan penelitian-penelitian sebelumnya, probiotik dapat memperbaiki metabolisme glukosa jika diberikan minimal selama 8 minggu $^{16,17}$. Secara teori, perubahan metabolisme glukosa tersebut dapat berefek pada peningkatan sensitivitas hepatic insulin yang dapat menyebabkan penurunan produksi VLDL di hepar sehingga kadar LDL plasma dapat menurun ${ }^{18}$. Oleh karena itu, penelitian selanjutnya disarankan untuk memberikan perlakuan probiotik selama minimal 8 minggu.

Hasil uji beda kadar LDL pre test dan post test pada masing-masing kelompok perlakuan pada penelitian ini memang tidak signifikan, tetapi uji beda kadar LDL post test pada kedua kelompok menunjukkan hasil yang berbeda signifikan. Hal ini menunjukkan bahwa yoghurt probiotik memberi efek yang lebih baik dalam melakukan perbaikan kadar LDL dibanding dengan yoghurt konvensional. Efek tersebut didapatkan melalui mekanisme dekonjugasi garam empedu melalui aktivitas bile salt hydrolase (BSH) serta asimilasi kolesterol yang dilakukan oleh probiotik sehingga penyerapan kolesterol dari usus berkurang. Akibatnya produksi LDL berkurang dan kadar LDL plasma menurun $^{19}$.

Selain waktu penelitian yang terbatas, penelitian ini juga memiliki kelemahan yaitu tidak semua subyek mengonsumsi obat anti hiperglikemia secara rutin selama masa perlakuan. Hal tersebut mungkin saja dapat berpengaruh terhadap kadar glukosa dan marker-marker komplikasi pada penyandang diabetes mellitus seperti kadar LDL $^{20}$. Penelitian ini merupakan penelitian pertama mengenai efek konsumsi yoghurt probiotik 
terhadap kadar LDL pada penyandang DM tipe 2 di Indonesia sehingga hasil penelitian ini dapat digunakan sebagai referensi penggunaan yoghurt probiotik untuk masyarakat terutama penyandang DM tipe 2. Hasil penelitian ini juga dapat digunakan sebagai referensi bagi penelitian selanjutnya untuk mengungkap efek yoghurt probiotik terhadap kadar LDL pada penyandang DM tipe 2.

\section{SIMPULAN}

Pemberian yoghurt probiotik yang mengandung $L$. acidophilus $L A-5$, dan $B$. animalis subsp. lactis $B B-12$ selama 4 minggu tidak dapat menurunkan kadar LDL pada penyandang DM tipe 2 secara signifikan. Pemberian yoghurt konvensional selama 4 minggu juga tidak dapat menurunkan kadar LDL pada penyandang DM tipe 2 secara signifikan. Meskipun demikian, efek yoghurt probiotik terhadap penurunan kadar LDL lebih baik dibanding yoghurt konvensional terbukti dengan adanya perbedaan yang signifikan kadar LDL post test antara subyek yang diberi yoghurt probiotik dan yoghurt konvensional. Kadar LDL pada masing-masing kategori asupan energi, protein, lemak, dan karbohidrat tidak berbeda signifikan. Pada penelitian selanjutnya, perlakuan sebaiknya dilakukan dengan durasi pelakuan yang lebih lama yaitu minimal 8 minggu. Selain itu, asupan zat gizi seperti asam lemak jenuh, asam lemak tidak jenuh, dan serat serta faktor lain yang dapat mempengaruhi hasil penelitian sebaiknya juga dianalisis untuk melihat ada tidaknya variabel pengganggu.

\section{UCAPAN TERIMA KASIH}

Penulis menyampaikan terima kasih kepada Fakultas Kedokteran, Kesehatan Masyarakat, dan Keperawatan Universitas Gadjah Mada yang telah memberikan dana hibah penelitian. Penulis juga berterima kasih kepada CHR. Hansen Indonesia yang telah mengirimkan sampel probiotik untuk penelitian. Ucapan terima kasih juga ingin penulis sampaikan pada seluruh enumerator yang telah membantu pengambilan data penelitian.

\section{DAFTAR PUSTAKA}

1. Bugger $\mathrm{H} \&$ Abel ED. Molecular mechanisms of diabetic cardiomyopathy. Diabetologia, 2014; 57(4): 660-671. doi: 10.1007/s00125-014-3171-6.

2. Pistrosch F, Natali A \& Hanefeld M. Is hyperglycemia a cardiovascular risk factor? Diabetes Care, 2011; 34(SUPPL. 2). doi:10.2337/dc11-s207.

3. Fox CS, Golden SH, Anderson C, Bray GA, Burke $\mathrm{LE}$, de Boer $\mathrm{IH}$, et al. Update on Prevention of
Cardiovascular Disease in Adults with Type 2 Diabetes Mellitus in Light of Recent Evidence. Circulation, 2015; 132: 691-718.

4. Tangvarasittichai S. Oxidative stress, insulin resistance, dyslipidemia and type 2 diabetes mellitus. World Journal of Diabetes, 2015; 6(3): 456-480. doi: 10.4239/wjd.v6.i3.456.

5. Ejtahed HS, Mohtadi-nia J, Homayouni-rad A, Niafar M, Asghari-jafarabadi M, Mofid V. Probiotic yogurt improves antioxidant status in type 2 diabetic patientss. Nutrition Journal, 2012; 28: 539-543. doi: 10.1016/j.nut.2011.08.013.

6. Rezaei M, Sanagoo A, Jouybari L, Behnampoo N \& Kavosi A. The Effect of Probiotic Yogurt on Blood Glucose and cardiovascular Biomarkers in Patientss with Type II Diabetes: A Randomized Controlled Trial. Evidence Based Journal, 2016; 6(4): 25-35. doi: 10.22038/ebcj.2016.7984.

7. Dirienzo DB. Effect of probiotics on biomarkers of cardiovascular disease: implications for hearthealthy diets. Nutrition Reviews, 2013; 72(1): 1829. doi: 10.1111/nure.12084.

8. Laitinen K, Poussa T, Isolauri E, et al. Probiotics and dietary counselling contribute to glucose regulation during and after pregnancy: a randomised controlled trial. The British journal of nutrition, 2009; 101(11): 1679-87. doi: 10.1017/S0007114508111461.

9. Joyce SA, MacSharry J, Casey PG, Kinsella M, Murphy EF, Shanahan F, et al. Regulation of host weight gain and lipid metabolism by bacterial bile acid modification in the gut. Proceedings of the National Academy of Sciences, 2014; 111(20): 7421-7426. doi: 10.1073/pnas.1323599111.

10. Perkeni. Pengelolaan dan pencegahan diabetes melitus tipe 2 di Indonesia 2015. Jakarta: 2015.

11. Moura CS, Lollo PCB, Morato PN, Esmerino EA, Margalho LP, Santos-junior VA, et al. Assessment of antioxidant activity, lipid profile, general biochemical and immune system responses of Wistar rats fed with dairy dessert containing Lactobacillus acidophilus La-5. Food Research International, 2016; 90: 275-280. doi: 10.1016/j.foodres.2016.10.042.

12. Everard A \& Cani PD. Best Practice \& Research Clinical Gastroenterology Diabetes, obesity and gut microbiota. Best Practice \& Research Clinical Gastroenterology, 2013; 27(1): 73-83. doi: 10.1016/j.bpg.2013.03.007.

13. Ivey KL, Hodgson JM, Kerr DA, Thompson PL, Stojceski B \& Prince RL. The effect of yoghurt and its probiotics on blood pressure and serum lipid profile; a randomised controlled trial. Nutrition, Metabolism and Cardiovascular Diseases, 2015; 25(1): 46-51. 
14. Singh RK, Chang HW, Yan D, Lee KM, Ucmak D, Wong $\mathrm{K}$, et al. Influence of diet on the gut microbiome and implications for human health. Journal of translational medicine, 2017; 15(1): 73 .

15. Koh A, De Vadder F, Kovatcheva-Datchary P \& Bäckhed F. From dietary fiber to host physiology: short-chain fatty acids as key bacterial metabolites. Cell, 2016; 65(6): 1332-1345.

16. Zhang Q, Wu Y \& Fei X. Effect of probiotics on glucose metabolism in patientss with type 2 diabetes mellitus : A meta-analysis of randomized controlled trials. Medicina. Lithuanian University of Health Sciences, 2016; 52(1): 28-34. doi: 10.1016/j.medici.2015.11.008.

17. Shah NJ \&Swami OC. Role of Probiotics in Diabetes: a Review of Their Rationale and Efficacy. Diabetes, 2017; 5[1]:104-110.
18. Gill JM \& Sattar N. Hepatic VLDL overproduction: is hyperinsulinemia or insulin resistance the culprit?. The Journal of Clinical Endocrinology \& Metabolism, 2011; 96 (7): 2032-2034.

19. Miremadi F, Ayyash M, Sherkat F, \& Stojanovska L. Cholesterol reduction mechanisms and fatty acid composition of cellular membranes of probiotic Lactobacilli and Bifidobacteria. Journal of Functional Foods, 2014 Jul 1;9:295-305.

20. Chaudhury A, Chitharanjan D, Dendi VSR, Kraleti S, Chada A, Ravilla R, et al. Clinical review of antidiabetic drugs: implications for type 2 diabetes mellitus management. Frontiers in endocrinology, 2017, 8 (6). 